\section{MANFAAT PENDIDIKAN DASAR BAGI ANGGOTA KOPERASI SIMPAN PINJAM CREDIT UNION PANCUR KASIH TEMPAT PELAYANAN BENGKAYANG} MARTONO

martono.bky@gmail.com

\author{
Akademi Manajemen Bumi Sebalo Bengkayang
}

Member Basic

Training;

Member

Responsibilities

\begin{abstract}
There are five pillars of credit cooperatives, namely Education, Self-help, Solidarity, Innovation and Unity. Basically Credit Union was born from the stage of education, developed through education and dependent on education. For this reason, every prospective member (community) who will join the Credit Union is required to attend education, because the educational aspect within the scope of the development of savings and loan cooperatives is very important. Plus the main goal of basic education is to recognize and deepen the ins and outs of Credit Union, the unification of vision and mission as a $n$ Credit Union Workshop Services. The method in this research is descriptive analysimember of Credit Union, changes in physical, mental, emotional, and spiritual aspects of life principles and paradigms, understanding history, financial intelligence, management regulations on AD / ART, and as a condition to become a member. Basic education for Credit Union members is an obligation for cooperatives as mentioned in the cooperative principle in Act Number 25 of 1992 Article 5 paragraph $2 a$. This study aims to determine the benefits of basic education for members of the Pancur Kasih Credit Unios method. This is ex post facto research. The population in this study was 8,000 members. The number of samples in this study were 80 members. Data collection techniques in this study are direct communication techniques (interview guidelines), indirect communication techniques (questionnaires), and documentary techniques (members' bad credit data). The results of this study indicate that there is a positive influence on the basic training of members of the responsibilities and obligations of members in the KSP CU Kasih Bengkayang TP. This can be seen from the tvalue of 5.632 which shows that there is an effect of the basic training of members on the responsibilities and the results of members' obligations. When compared with t table at the 0.05 significance level of 1.992, so Ha is accepted. The conclusion of this study is the basic training of members has a significant effect on the responsibilities and obligations of members in the KSP CU Kasih Bengkayang TPU
\end{abstract}

Keywords: CU KSP, Member Basic Training, Member Responsibilities and Obligations 
Member Basic

Training;

Member

Responsibilities

\section{PENDAHULUAN}

\section{Latar Belakang}

Pemerintahan Indonesia saat ini sedang berupaya mengatasi masalah krisis ekonomi beserta dampak yang ditimbulkannya. Hal itu dilakukan dengan melakukan pembenahan-pembenahan terhadap strategi ekonomi yang telah dilaksanakan sebelumnya melalui proses reformasi di bidang ekonomi yaitu pertumbuhan ekonomi disertai dengan mengurangi penduduk dibawah garis kemiskinan. Hal demikian diperlukan suatu perencanaan yang sangat panjang bagi semua pelaku di dalam perekonomian termasuk sektor koperasi, karena koperasi dipandang sebagai salah satu lembaga yang lebih baik dan lebih mampu, dikarenakan usaha yang dikelolanya dalam menciptakan kesejahteraan anggota dan masyarakat majemuk. Dikatakan demikian karena koperasi adalah suatu badan usaha ekonomi yang bergabung secara sukarela atas dasar persamaan hak, kewajiban, serta melakukan suatu usaha yang bertujuan memenuhi kebutuhan-kebutuhan para anggotanya.

Program Pendidikan dasarmerupakan upaya untuk mengembangkan kemampuan-kemampuan intelektual dan kepribadian manusia. Program pendidikan dan pelatihan, sebenarnya telah diselenggarakan secara rutin oleh Koperasi Simpan Pinjam Credit Union Pancur Kasih Tempat Pelayanan Bengkayang yang kemudian disingkat KSP CU Pancur kasih TP Bengkayang. Program pendidikan dasarsebagai salah satu aspek peningkatan kinerja koperasi, juga dilakukan oleh KSP CU Pancur kasih TP Bengkayang. Pelaksanaan pendidikan dasaryang dilakukan diprioritaskan pada pengelola koperasi, baik pendidikan dalam bidang manajemen operasional maupun manajemen keuangan. Bidang manajemen operasional dengan tujuan agar pengelola koperasi mempunyai strategi yang handal dalam menghadapi persaingan yang kompetitif. Disisi lain pembinaan bidang manajemen ini diharapkan pula pengelola mampu mengembangkan pangsa pasar karena saat ini koperasi hanya mengandalkan pasar internal atau hanya mengandalkan partisipasi anggota.

Credit Union adalah sebuah gerakan yang menyediakan fasilitas intermediasi keuangan. World Council of Credit Unions (WOCCU) menuliskan bahwa Credit Union memberikanlebih dari sekadar fasilitas jasa keuangan kepada seluruh lapisan masyarakat. CreditUnion menyediakan kesempatan bagi seluruh anggotanya untuk memiliki lembagakeuangan anggota sendiri, membantu anggota menciptakan peluang-peluang seperti memulai sebuah usaha kecil, mengembangkan lahan 
pertanian, membangun rumah tinggal, dan mendidik anak-anak anggota. Singkatnya, WOCCU menegaskan bahwa keberadaan Credit Union bertujuan untuk meningkatkan kesejahteraan anggotanya, baik secara finansial maupun nonfinansial.

Member Basic Training; Member Responsibilities

Tujuan yang tidak hanya diukur secara finansial inilah yang membedakan Credit Union dengan bentuk lembaga keuangan lainnya. Berbicara lebih lanjut mengenai suatu gerakan, tidak mungkin melepaskan aspek kemanusiaan yang melekat kuat di setiap kegiatan operasional Credit Union. Salah satu aspek kemanusiaan yang paling nyata di tubuh lembaga ini adalah keberadaan satu benang merah yang mengikat setiap anggota dari suatu Credit Union. McKillop \& Wilson (2015, hal. 9) memaparkan bahwa ikatan utama antaranggota didasarkan pada kesamaan komunitas, pekerjaan, dan asosiasi. Bila ditarik lebih jauh lagi, ikatan ini terkait pula pada tataran adat istiadat dan lokasi tempat Credit Union itu berada. Kedua hal ini merupakan fondasi penting bagi sebuah Credit Union untuk dapat diterima di tengah masyarakat sesuai dengan kondisi demografis, sosiologis, dan geografis anggota.

Aspek kemanusiaan yang kedua merujuk pada kepemilikan Credit Union. Pemilik Credit Union adalah anggota-anggotanya. Keberlangsungan lembaga ini ditentukan oleh dinamika seluruh anggotanya yang memiliki peran sebagai penabung, peminjam, dan investor. Dalam prakteknya anggota sebagai penabung dan peminjam bersinggungan satu sama lain. Di satu sisi, sebagai penabung, anggota menghendaki balas jasa simpanan yang tinggi. Di sisi lain, sebagai peminjam, anggota menginginkan akses pinjaman berbunga rendah. Persinggungan kedua peran ini merupakan salah satu konflik sangat potensial yang perlu disadari oleh seluruh anggotanya sejak awal. Penyadaran konflik tersebut adalah salah satu pekerjaan pengurus dan pengelola Credit Union melalui pendidikan kepada seluruh anggotanya. Pemaknaan peran investor dalam diri anggota lebih dititikberatkan pada kepemilikan lembaga melalui acara Rapat Anggota Tahunan (RAT). Dalam acara tersebut, anggota tidak hanya menerima laporan operasional Credit Union selama satu tahun, tetapi juga menerima manfaat finansial dari kelebihan hasil kegiatan usaha Credit Union, yakni Surplus Hasil Usaha (SHU).

Kepemilikan berbasis anggota dalam satu ikatan yang sama menjadi salah satu hal yang mempengaruhi perkembangan Credit Union. Dari sudut pandang pengelolaan lembaga, ikatan yang sama pada setiap anggota akan mengurangi biaya 
Member Basic

Training;

Member

Responsibilities

101 informasi tentang calon peminjam. Hal ini merupakan salah satu bentuk efisiensi biaya operasional Credit Union. Selain itu, ikatan tersebut berdampak pula pada berkurangnya resiko kegagalan pengembalian pinjaman (Black \& Duggar, 1981, dikutip oleh McKillop \& Wilson, 2015, hal. 9). Mengenai ikatan yang sama pada setiap anggota, Kusumajati (2012, hal. 7) menambahkan bahwa adat dan budaya lokal yang dimiliki bersama dan diwariskan secara turun-temurun menjadi pertimbangan penting dalam perumusan produk-produk Credit Union, mekanisme kerja, dan penyelesaian masalah operasional, seperti penyelesaian pinjaman tidak lancar dilakukan dengan memanfaatkan tekanan sesama anggota.

Selain sistem analisis kredit yang dilaksanakan oleh manajemen Credit Union, pencegahan dapat dilakukan melalui pendidikan kepada anggota Pendidikan adalah salah satu pilar utama di Credit Union selain pilar solidaritas, swadaya, dan inovasi. Dari sudut pandang operasional, Munaldus, Karlena, \& Herlina (2014, hal. xxv) menerjemahkan pilar tersebut dengan menggarisbawahi pernyataan dari Romo Albrecht Karim Arbie, seorang pastur dari Serikat Yesuit, bahwa permulaan CU dimulai dari pendidikan, perkembangannya dilakukan melalui pendidikan, dikontrol oleh pendidikan, dan bergantung pada pendidikan. Dengan demikian, pendidikan sudah seharusnya dimaknai sebagai sarana penting untuk kemajuan dan keberlanjutan sebuah Credit Union.

Selama ini, praktik pendidikan yang berlangsung di Credit Union primer diadakan dalam rangka memenuhi salah satu persyaratan wajib bagi calon anggota untuk bergabung sebagai anggota. Munaldus, Karlena, \& Herlina (2014, hal. 28) menyatakan bahwa Pendidikan Dasar di Credit Union dibagi menjadi dua bagian, yakni Pendidikan Dasar I dan Pendidikan Dasar II. Pendidikan Dasar I ditujukan kepada calon anggota yang sudah menerima sosialisasi tentang Credit Union. Materi Pendidikan Dasar I memuat sejarah CreditUnion, keorganisasian Credit Union, manajemen keuangan pribadi (keluarga), pengantar manajemen kredit, dan pola kebijakan Credit Union setempat. Pendidikan Dasar I, idealnya, dilakukan selama dua hari.

Sasaran peserta Pendidikan Dasar II adalah anggota-anggota Credit Union yang sudah mengikuti Pendidikan Dasar I. Pendidikan yang berdurasi 2-3 hari ini bertujuan untuk meningkatkan pengetahuan, wawasan, penghayatan, dan 
keterampilan anggota dalam berkomunitas di Credit Union. Namun, pada kenyataannya, ada Credit Union yang memangkas beberapa materi inti dalam Pendidikan Dasar I dan II, menggabungkan pangkasan-pangkasan tersebut kemudian mempersingkat durasi waktu pendidikan menjadi satu hari, bahkan beberapa jam saja.

Lebih jauh lagi, Munaldus, Karlena, \& Herlina (2014, hal. 157) menerangkan bahwa materi pendidikan Credit Union sebanyak 80\% harus berisi kecerdasan emosi, kecerdasan dalam menghadapi kesulitan, dan kecerdasan spiritual. Sisanya sebanyak $20 \%$ adalah materi terkait hal-hal teknis seperti keorganisasian, produk dan pelayanan, perhitungan balas jasa simpanan, perhitungan bunga pinjaman, dantata cara pengajuan pinjaman. Sayangnya, dalam praktik riilnya, persentase materi di atas justru terbalik.

Setelah pendidikan dasar bagi calon anggota, ada pendidikan lanjutan bagi anggota, yakni pendidikan literasi keuangan. Dari beberapa poin yang disampaikan oleh Munaldus, Karlena, \& Herlina (2014, hal. 158-160), materi dalam pendidikan literasi keuangan lebih menekankan pada internalisasi pembedaan konsep kebutuhan dan keinginan, pembelajaran tentang perencanaan keuangan yang lebih komprehensif, internalisasi filosofi Credit Union dan anggota anggotanya sebagai satu kesatuan yang saling menghidupi.

McKillop \& Wilson (2015, hal. 11) menyatakan, aktivitas dan inisiatif dalam pendidikan dan literasi keuangan merupakan hal pokok dari karakter sosial dan ekonomi sebuah Credit Union dalam melayani kebutuhan anggota-anggotanya. Lebih lanjut, McKillop \& Wilson (2015, hal. 16) menambahkan, salah satu tanggung jawab sosial dari sebuah Credit Union adalah memajukan pendidikan keuangan, yang merupakan prinsip inti koperasi, kepada seluruh anggotanya. Sayangnya, tanggung jawab ini cenderung dilakukan secara sederhana dalam rangkaian waktu yang terputus-putus atau tidak rutin pelaksanaannya. Tidak heran bila dampak dari implementasi yang demikian tidak dinikmati oleh semua anggota.

Pernyataan-pernyataan di atas semakin menekankan pentingnya literasi keuangan dan pendidikan keuangan bagi setiap orang. Apabila ditelaah lebih lanjut dalam konteks Credit Union yang merupakan sebuah gerakan dari kumpulan anggota yang saling percaya, maka pendidikan merupakan salah satu sarana penting untuk 
Member Basic Training; Member Responsibilities

\section{3}

memajukan seluruh anggotanya supaya peran anggota tidak terbatas pada status penabung dan peminjam saja, tetapi juga ikut serta membangun pertumbuhan Program pendidikan dasardalam bidang keuangan dengan tujuan agar pengelola mampu mengefektifkan modal yang dimiliki sehingga koperasi dapat berkembang dengan pesat. Tingkat perputaran kas yang tinggi tentunya akan memberikan peranan positif bagi pendapatan koperasi dan hal ini akan dapat mendukung pencapai target keuntungan (SHU) koperasi. Notoatmodjo (2009:18), mengemukakan bahwa pendidikan dasarakan meningkatkan kemampuan atau keterampilan para karyawan, meningkatkan produktivitas kerja para karyawan. Produktivitas kerja para karyawan meningkat, berarti organisasi yang bersangkutan akan memperoleh keuntungan. Peningkatan kinerja karyawan mempunyai implikasi bahwa dengan keterampilan yang dimiliki, maka karyawan akan dapat meningkatkan produktivitas dan efisiensi dalam pengelolaan keuangan sehingga keuntungan perusahaan. Peningkatan modal tentunya diharapkan akan mampu meningkatkan keuntungan perusahaan secara efektif, di mana penambahan modal (marginal capital) harus mampu memberikan peningkatan yang lebih besar terhadap keuntungan (marginal profit)

Alasan utama pentingnya pemberdayaan koperasi diawali dari sebuah keyakinan bahwa kelompok masyarakat yang berada pada kondisi ekonomi kelas bawah akan relatif lebih mudah diperjuangkan kepentingan ekonominya melalui koperasi. Tentu saja keyakinan tersebut harus didukung dengan kualitas koperasi yang baik. Dengan demikian upaya untuk membuat koperasi sebagai sebuah lembaga ekonomi yang tangguh menjadi sebuah keharusan. Salah satu bentuk usaha koperasi yang berkembang saat ini adalah bidang usaha simpan pinjam dikelola oleh koperasi kredit atau lebih dikenal dengan usaha Credit Union $(C U)$ terutama di Kalimantan Barat.

Ada lima pilar koperasi kredit, yakni Pendidikan, Swadaya, Solidaritas, Inovasi dan Persatuan. Pada dasarnya Credit Union lahir dari tahapan pendidikan, berkembang melalui pendidikan dan bergantung dari pendidikan. Oleh karena itu, setiap calon anggota (masyarakat) yang akan bergabung dengan Credit Union wajib untuk mengikuti pendidikan, karena aspek pendidikan dalam lingkup pengembangan koperasi simpan pinjam sangat penting. Ditambah tujuan utama pendidikan dasar adalah untuk mengenal dan memperdalam seluk beluk Credit Union, penyamaan visi misi sebagai anggota Credit Union, perubahan- perubahan aspek mental, emosional, 
perubahan prinsip dan paradigma hidup, memahami sejarah, kecerdasan finansial, Member Basic

peraturan pengurus tentang AD/ART, serta sebagai syarat untuk menjadi anggota.

Secara umum, pengertian pendidikan dasarperkoperasian adalah pendidikan Responsibilities bagi anggota koperasi agar lebih memahami tentang seluk beluk koperasi, melalui penyuluhan, pelatihan dan studi banding ke koperasi yang lain. Menurut Sudarsono

(2004:37) pendidikan dasarperkoperasian adalah kegiatan-kegiatan yang dilaksanakan untuk membuat para anggota, perangkat koperasi seperti pengurus, pengawas, dan dewan penasehat termasuk staf karyawan koperasi sadar akan ideologi koperasi, praktek usaha dan metode kerjanya.

Pendidikan dasarperkoperasian merupakan kegiatan penularan ilmu/ pengetahuan perkoperasian serta peningkatan keterampilan teknis yang dilakukan secara terus menerus dan berkesinambungan oleh koperasi dan atau pihak-pihak di luar koperasi yang terarah kepada unsur-unsur gerakan koperasi dan masyarakat dengan tujuan agar anggota koperasi meningkat pengetahuan, pemahaman, kesadaran, keperilakuan dan keterampilannya dalam berkoperasi serta masyarakat menjadi tahu, mengerti dan termotivasi menjadi anggota koperasi secara sukarela.

Pendidikan dasarperkoperasian merupakan hal yang penting dalam pembinaan dan pengembangan koperasi karena keberhasilan atau kegagalan koperasi banyak bergantung pada tingkat pendidikan yang dampaknya akan meningkatkan partisipasi anggota. Oleh karena itu, pendidikan dasarsangat diperlukan untuk memberikan bekal yang memadai kepada anggota, agar anggota dapat berperan secara aktif dan dinamis.

Pendidikan awal atau pendidikan dasar para calon anggota mendapatkan orientasi tentang sejarah Credit Union, analisis sosial, anggaran belanja keluarga, cara menabung, meminjam, uang pangkal, simpanan pokok, simpanan wajib, simpanan sukarela, angsuran pinjaman, bunga denda, sisa hasil usaha pencocokan antar buku anggota dengan 3 catatan yang ada pada bendahara, dan semua yang menyangkut tentang kegiatan-kegiatan koperasi simpan pinjam, sehingga menumbuhkan kesadaran akan kewajiban dan tanggungjawabnya sebagai anggota agar tujuan pendirian Credit Union dapat berjalan sebagaimana mestinya. Di samping hal tersebut pendidikan dasar bagi anggota Credit Union merupakan kewajiban bagi koperasi sebagaimana yang sudah disebutkan dalam prinsip koperasi pada Undang- 
Member Basic

Training;

Member

Responsibilities

105
Undang Nomor 25 Tahun 1992 Pasal 5 ayat 2a. Selain itu, ketika anggota telah mengikuti pendidikan dasar anggota akan memperoleh sertifikat pendidikan dasar yang nanti akan digunakan sebagai salah satu persyaratan pengajuan pinjaman.

Pelaksanaan pendidikan dasar diharapkan memiliki pengaruh yang signifikan sebagaimana harapan bersama. Harapan yang dimaksud adalah semakin besar tingkat kesadaran dan tanggung jawab anggota serta partisipasi anggota melaksanakan kerjasama sebagai jaminan masa depan. Jaminan tersebut diantaranya; aktif menabung, membayar iuran kredit secara aktif, melunasi simpanan pokok sebagaiman telah ditetapkan dalam anggaran dasar, mematuhi anggaran dasar dan anggaran rumah tangga, berpartisipasi dalam usaha koperasi, menghadiri dan menyatakan pendapat serta suara dalam rapat anggota, mengembangkan dan memelihara kebersamaan sesama anggota, serta menambah pengetahuan perkoperasian.

Berdasarkan hasil observasi pra riset yang penulis lakukan di KSP CU Pancur Kasih TP Bengkayang, ditemukan bahwa keseluruhan dari anggota KSP CU Pancur Kasih TP Bengkayang telah mengikuti kegiatan pendidikan dasar yang sesuai jadwal yang telah ditetapkan. Akan tetapi, dalam pelaksanaannya masih ada sebagian dari anggota melalaikan kewajiban dan tanggungjawabnya sebagai anggota.

Berangkat dari latar belakang yang ada, maka penulis ingin mengetahui "Apa saja manfaat pendidikan dasar bagi anggota KSP CU Pancur Kasih TP Bengkayang"?. Sehingga, untuk mengetahui Apa saja manfaat pendidikan dasar bagi anggota KSP CU Pancur Kasih TP Bengkayang tersebut, maka peneliti melakukan penulisan dengan judul "Manfaat pendidikan dasar bagi anggota koperasi simpan pinjam Credit Union Pancur Kasih Tempat Pelayanan Bengkayang”.

\section{Permasalahan}

Berdasarkan latar belakang yang telah dikemukakan diatas, maka yang menjadi permasalahan dalam penelitian ini adalah "Apa saja manfaat pendidikan dasar bagi anggota koperasi simpan pinjam Credit Union pancur kasih bengkayang?” 


\section{Kerangka Pemikiran}

Pendidikan Keuangan Lingkungan finansial yang dihadapi saat ini memiliki tingkat kompleksitas yang lebih berbahaya bagi individu dalam membuat keputusan finansialnya (Boshara, Gannon, Mandell, Phillips, \& Sass, 2010, hal. 5).

ember Basic Training; Member Responsibilities Ketidakcukupan pemahaman konsep finansial pada individu diidentifikasi sebagai penghalang potensial dari setiap upaya pengembangan kebijakan lembaga. Hal tersebut juga menjadi pertanyaan penting untuk lembaga keuangan mengenai efektivitas usaha penyelenggaraan pendidikan keuangan selama ini terutama bagi anggota yang rentan (Moore, 2003, hal. 28).

OECD (2005b, hal. 13, 26) menuliskan pengertian pendidikan keuangan sebagai berikut:

Financial education is the process by which financial consumers/investors improve their understanding of financialproducts and concepts and through information, instruction and/or objective advice, develop the skills and confidence to become aware of financial risks and opportunities, to make informed choices, to know where to go for help and to take other effective actions to improve their financial well-being.

Pendidikan keuangan adalah proses bagi anggota/investor keuangan guna meningkatkan pemahaman tentang konsep, produk keuangan, instruksi dan/atau saran objektif melalui informasi, guna mengembangkan keterampilan dan kepercayaan diri untuk menjadi sadar terhadap peluang dan risiko (keuangan), guna menetapkan pilihan, guna mengetahui tempat mencari bantuan, dan guna mengambil tindakan efektif lainnya dalam rangka mengembangkankesejahteraan finansial anggota.

OECD menganjurkan program pendidikan keuangan sebaiknya fokus pada aspek perencanaan hidup terkait tabungan, pinjaman, asuransi, dan pensiun. Dalam surveinya, FINRA (2009, hal. 5) menekankan empat komponen kemampuan keuangan, yakni mampu memenuhi kebutuhan, membuat perencanaan, mengelola produk keuangan, serta memiliki pengetahuan keuangan dan membuat keputusan finansial.

Yoong \& Ferreira (2011, hal. 12) menjelaskan lebih lanjut bahwa bagi anggota, ada hubungan antara pendidikan keuangan dengan perilaku finansial perencanaan lebih baik, penggunaan pinjaman lebih tepat, dan pertambahan kekayaan- yang 
Member Basic Training; Member Responsibilities

107

mengarah pada kehidupan finansial lebih sejahtera. Sementara itu, bagi industri jasa keuangan, peningkatan permintaan produk-produk keuangan, daya saing lembaga, transparansi lembaga, dan peningkatan efisiensi adalah dampak dari partisipasi anggota yang diedukasi dengan baik.

Hogarth (2006, hal. 1) menjelaskan bahwa anggota yang teredukasi dengan baik akan menciptakan riak-riak ekonomi bagi sekitarnya, tidak hanya untuk diri sendiri. Anggota mampu membuat keputusan finansial dengan lebih baik untuk kepentingan pribadi maupun keluarga, serta mampu meningkatkan kesejahteraan hidup.

Mengakses atau meningkatkan pemahaman finansial jelas sekali urgensinya bagi anggota dalam menghadapi perubahan kondisi ekonomi. Dengan semakin kompleksnya produk dan jasa keuangan, individu dihadapkan pada tanggung jawab lebih besar terkait pengelolaan keuangan pribadinya, bahkan keuangan keluarganya. Untuk mampu bertanggung jawab atas segala keputusan finansialnya, individu memerlukan pendidikan keuangan yang memadai. Terkait pendidikan dispesifikkan lagi berdasarkan karakteristik Credit Union. Ada beberapa jenis pendidikan yang diselenggarakan di Credit Union. Namun, subbab ini hanya memaparkan pendidikan yang dikhususkan untuk (calon) anggota-anggota, yakni Pendidikan Dasar dan Pendidikan Literasi Keuangan.

Menurut UU Nomor: 25 Tahun 1992 dalam Sitio dan Tamba (2001: 84-85) modal koperasi di Indonesia terdiri dari:

1. Modal Sendiri bersumber dari:

a. Simpanan pokok anggota yaitu sejumlah uang yang sama banyaknya yang wajib dibayarkan masing-masing anggota kepada koperasi pada saat masuk menjadi anggota dan sifatnya adalah permanent artinya tidak dapat diambil bila yang bersangkutan masih merupakan anggota.

b. Simpanan wajib anggota yaitu sejumlah simpanan tertentu yang tidak harus sama benyaknya tetapi wajib dibayarkan kepada koperasi pada periode tertentu. Simpanan ini dapat diambil selama orang yang bersangkutan masih menjadi anggota.

c. Dana cadangan yaitu sejumlah dana yang diperoleh dari penyesihan sisa hasil usaha dan dicadangkan untuk menutup kerugian koperasi jika diperlukan. 
d. Donasi atau hibah yaitu sejumlah uang atau barang dengan nilai tertentu yang disumbangkan oleh pihak ketiga tanpa ada suatu ikatan atau kewajiban untuk mengembalikannya.

Member Basic Training;

Member Responsibilities

2. Modal pinjaman atau modal luar bersumber dari:

a. Anggota yaitu pinjaman dari anggota atau calon anggota yang bersangkutan

b. Koperasi lain dan tau anggotanya yaitu pinjaman yang berasal dari koperasi lain dan atau anggotanya yang didasari dengan perjanjian kerjasama antara koperasi

c. Bank dan lembaga keuangan lainnya yaitu pinjaman dari bank dan lembaga keuangan lainnya yang dilakukan berdasarkan ketentuan peraturan perundang-undangan yang berlaku

d. Penerbitan obligasi dan surat uatang lainnya yaitu dana yang diperoleh dari penerbitan obligasi dan surat utang lainnya berdasarkan ketentuan perundang-undangan yang berlaku.

Di samping itu koperasi juga telah dijelaskan dalam Undang-Undang No. 25 tahun 1992, Bab 1, Pasal 1, Ayat 1 menyatakan koperasi adalah "Badan usaha yang beranggotakan orang seorang atau badan hukum koperasi dengan melandaskan kegiatannya berdasarkan prinsip koperasi sekaligus sebagai gerakan ekonomi rakyat yang berdasarkan atas asas kekeluargaan”. Dalam pelaksanaanya, kegiatan koperasi dikembangkan untuk mewujudkan demokrasi ekonomi yang antara lain masuk dalam pemerataan pendapatan di masyarakat melalui pertumbuhan koperasi- koperasi yang sehat. Hal ini sejalan dengan Undang-Undang Nomor 25 tahun 1992 tentang perkoperasian pasal 3 yang menyatakan bahwa, koperasi bertujuan memajukan kesejahteraan anggota pada khususnya dan masyarakat pada umumnya, serta ikut membangun tatanan 2 perekonomian nasional, dalam rangka mewujudkan masyarakat yang maju, adil, dan makmur berlandaskan Pancasila dan UndangUndang Dasar 1945.

\section{METODE PENELITIAN}

Metode penelitian yang digunakan adalah metode deskriptif dan bentuk penelitian yang digunakan, yaitu studi hubungan (interrelationship studies) untuk mengetahui apakah terdapat hubungan antara dua variabel atau lebih, tanpa 
Member Basic Training; Member Responsibilities melakukan perubahan, tambahan atau manipulasi terhadap data yang memang sudah ada (Hadari Nawawi, 2015:68). Populasi yang digunakan dalam penelitian ini adalah seluruh anggota KSP CU Pancur Kasih TP Bengkayang dengan jumlah 8.000 anggota. Untuk jumlah sampel anggota yang digunakan pada penelitian ini berjumlah 80 orang anggota. Teknik pengumpulan data dalam penelitian ini menggunakan teknik komunikasi tidak langsung, teknik komunikasi langsung, dan teknik studi dokumenter dengan instrument (alat) pengumpulan data yang digunakan yaitu, lembar kuisioner atau angket, pedoman wawancara, dan lembar catatan berupa data yang berhubungan.

Untuk penelitian ini, peneliti juga menggunakan teknik pengukuran data untuk angket dengan memberi bobot pernyataan, dimana item-item instrumen yang berupa pernyataan positif terdiri atas lima pilihan jawaban yang berupa sangat setuju (SS), setuju (S), ragu-ragu (RR), kurang setuju (KS) dan tidak setuju (TS). Dalam penelitian ini, responden dapat memberikan tanda checklist $(\sqrt{ })$ untuk jawaban yang sesuai dengan keadaannya.

Rencana pengolahan data yang digunakan dalam penelitian ini ada beberapa macam. Pertama, uji instrumen untuk mengetahui apakah data yang digunakan valid dan reliabel untuk penelitian, Dari hasil uji valid dengan membandingkan $r$ hitung dan $\mathrm{r}$ tabel, maka diketahui sebanyak 29 item pernyataan dari 32 item variabel pendidikan dasar anggota yang dinyatakan valid dan 7 dari 11 item pernyataan variabel kewajiban dan tanggungjawab anggota yang dinyatakan valid. Hasil reliabel menunjukan nilai alfa cronbach di atas 0,745. Kedua, penulis melakukan uji normalitas dan linearitas untuk mengetahui apakah data penelitian berdistribusi normal dan memiliki hubungan yang linear sebagai syarat uji statistik parametrik. Ketiga, penulis melakukan uji regresi linear sederhana dengan bantuan SPSS versi 20.0 untuk mengetahui apakah terdapat pengaruh variabel $\mathrm{x}$ (pendidikan dasar anggota) terhadap variabel y (kewajiban dan tanggungjawab anggota) dengan dimasukan dalam rumus persamaan regresi di bawah ini.

$\mathrm{Y}^{\prime} \quad=\mathrm{a}+\mathrm{bX}$

\section{Keterangan:}

$\mathrm{Y}^{\prime} \quad$ = Nilai yang diprediksikan

a = konstanta atau bila harga $\mathrm{X}=0$ 
$\mathrm{b} \quad=$ Koefisien regresi

$\mathrm{X}=$ Nilai variabel independen (Sugiyono, 2015: 262)

Member Basic

Training;

Member

Responsibilities

menguji hipotesis dalam penelitian dengan membandingkan nilai signifikansi 0,05. Jika $r$ hitung lebih kecil dari $r$ tabel, maka Ho diterima dan Ha ditolak dan bila $r$ hitung lebih besar dari $\mathrm{r}$ tabel $(\mathrm{rh}>\mathrm{rt}$ ), maka Ha diterima dan Ho ditolak

\section{HASIL DAN PEMBAHASAN}

Dalam penelitian ini, data yang dikumpulkan digunakan untuk mengetahui masalah dalam penelitian ini, yaitu "Apa saja manfaat pendidikan dasarbagi anggota koperasi simpan pinjam Credit Union pancur kasih bengkayang ?’. Data yang dikumpulkan dalam penelitian ini adalah data variabel pendidikan dasar anggota sebagai variabel $\mathrm{X}$ dan data variabel kewajiban dan tanggungjawab anggota sebagai variabel Y. Data variabel pendidikan dasar anggota (variabel X) diperoleh dari hasil penyebaran angket pendidikan dasar anggota kepada 80 orang responden dengan jumlah item pernyataan sebanyak 39 pernyataan dan data variabel kewajiban dan tanggungjawab anggota sebanyak 17 item pernyataan, dimana hasil angket tersebut berguna untuk mengetahui bagaimana pendidikan dasar anggota dan kewajiban dan tanggungjawab anggota pada KSP CU Pancur Kasih TP Bengkayang. Hasil jawaban responden pada angket pendidikan dasar anggota dan kewajiban dan tanggungjawab anggota tersebut masih berbentuk data kualitatif, maka dari itu hasil angket tersbeut harus ditransformasikan ke dalam bentuk data kuantitatif dengan memberikan skor pada jawaban responden.

Tabel 1. Analisis Deskriptif Variabel Pendidikan Dasar Anggota

\begin{tabular}{|l|l|l|l|l|}
\hline $\begin{array}{l}\text { Persentase Hasil Analisis Deskriptif } \\
\text { Pendidikan Dasar Anggota } \\
\text { Variabel X dan Sub variabel }\end{array}$ & $\begin{array}{l}\text { Skor } \\
\text { ideal }\end{array}$ & $\begin{array}{l}\text { Skor } \\
\text { aktual }\end{array}$ & $\%$ & Kategori \\
\hline Pendidikan dasar anggota & 11.165 & 9.630 & $86,25 \%$ & Sangat tinggi \\
\hline a. Materi Pendidikan Dasar & 7.315 & 6.073 & $83,02 \%$ & Sangat tinggi \\
\hline b. Waktu Pendidikan Dasar & 1.155 & 955 & $82,68 \%$ & Sangat tinggi \\
\hline c. Tempat Pendidikan Dasar & 1.155 & 963 & $83,37 \%$ & Sangat tinggi \\
\hline
\end{tabular}




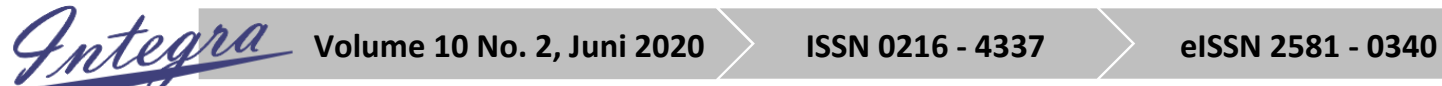

Member Basic

Training;

Member

Responsibilities

\begin{tabular}{|l|l|l|l|l|}
\hline d. Suasana Pendidikan Dasar & 1.155 & 948 & $82,07 \%$ & Sangat tinggi \\
\hline $\begin{array}{l}\text { e. Sarana dan prasarana Pendidikan } \\
\text { dasar }\end{array}$ & 770 & 691 & $89,74 \%$ & Sangat tinggi \\
\hline
\end{tabular}

Berdasarkan tabel 1 dapat diketahui bahwa pendidikan dasar anggota pada KSP

CU Pancur Kasih TP Bengkayang memiliki skor aktual 9630 dan skor ideal 11.165 dengan besar persentase sebesar 86,25\% dan tergolong dalam kategori sangat tinggi. Hal ini menunjukkan bahwa secara umum materi pendidikan dasar yang disampaikan mudah dipahami oleh anggota, waktu pelaksanaan pendidikan dasar sesuai dengan situasi dan kondisi anggota, tempat pendidikan dasar mudah dijangkau, suasana pendidikan dasar nyaman serta sarana dan prasarana sangat mendukung pelaksanaan pendidikan dasar yang dilaksanakan oleh KSP CU Pancur Kasih TP Bengkayang.

Tabel 2. Analisis Kewajiban dan Tanggungjawab Anggota

\begin{tabular}{|l|l|l|l|l|}
\hline $\begin{array}{l}\text { Hasil Analisis Kewajiban dan Tanggungjawab } \\
\text { Anggota Variabel dan Sub Variabel }\end{array}$ & $\begin{array}{l}\text { Skor } \\
\text { ideal }\end{array}$ & $\begin{array}{l}\text { Skor } \\
\text { aktual }\end{array}$ & \% & Kategori \\
\hline KEWAJIBAN ANGGOTA & 1.925 & 1.488 & $77,29 \%$ & Tinggi \\
\hline a. Mematuhi AD/ART & 770 & 618 & $80,25 \%$ & Sangat Tinggi \\
\hline b. Menghadiri RAT & 385 & 224 & $58,18 \%$ & Cukup \\
\hline c. Membayar kredit & 385 & 325 & $84,41 \%$ & Sangat Tinggi \\
\hline d. Membayar simpanan & 385 & 321 & $83,37 \%$ & Sangat Tinggi \\
\hline TANGGUNGJAWAB ANGGOTA & 770 & 486 & $63,11 \%$ & tinggi \\
\hline a. Berpartisipasi dalam kegiatan usaha & 385 & 237 & $61,55 \%$ & Tinggi \\
\hline Mengembangkan dan memelihara kebersamaan & 385 & 249 & $64,67 \%$ & Tinggi \\
\hline
\end{tabular}

Analisis Deskriptif Kewajiban Dan Tanggungjawab Anggota

Berdasarkan hasil analisis persentase kewajiban dan tanggungjawab pada tabel 2 dapat diketahui bahwa skor aktual untuk kewajiban anggota sebesar 1.488 dan skor ideal sebesar 1.925. Adapun besarnya persentase kewajiban anggota pada KSP CU Pancur Kasih TP Bengkayang yakni 77,29\%. deskriptif persentase maka dapat dikatakan bahwa kewajiban anggota pada KSP CU Pancur Kasih TP Bengkayang tergolong tinggi, dimana anggota aktif menabung, melakukan pinjaman, dan 
membayar angsuran, anggota juga aktif mengajak orang lain, keluarga maupun kerabat untuk bergabung di CU Pancur Kasih

Member Basic Training;

Member

Responsibilities untuk mengetahui apakah terdapat pengaruh antara variabel $\mathrm{X}$ (pendidikan dasar anggota) terhadap variabel Y (kewajiban dan tanggungjawab anggota), maka penulis menggunakan teknik uji regresi linear sederhana. Dari hasil uji regresi linear sederhana diperoleh nilai konstanta (a) dari variabel pendidikan dasar anggota adalah 33,722, nilai koefisien regresi (b) sebesar 0,138, nilai t hitung sebesar 5.632 dan nilai signifikansi 0.000 sehingga jika dimasukan ke dalam rumus persamaan regresi linear sederhana dari Sugiyono (2015: 262), maka akan diperoleh persamaan sebagai berikut.

$\mathrm{Y}=\mathrm{a}+\mathrm{bx}$

$\mathrm{Y}=33,722+0,138 \mathrm{x}$

\section{Uji hipotesis}

Penulis juga melakukan uji hipotesis dengan menggunakan uji t, dimana uji t ini bertujuan untuk mengetahui apakah terdapat pengaruh variable pendidikan dasar anggota (variabel X) terhadap kewajiban dan tanggungjawab anggota (variabel Y). Dari hasil uji hipotesis yang telah dilakukan penulis, maka dapat diketahui nilai $\mathrm{t}$ hitung sebesar 5,632 dan nilai t tabel sebesar 1,992 sehingga dapat disimpulkan nilai t hitung lebih besar daripada t tabel, maka Ha diterima dan Ho ditolak. Jika dilihat dari signifikansinya, nilai signifikan dari tabel 4.10 sebesar 0,000 artinya nilai signifikansi kurang dari 0,05 sehingga Ha diterima dan Ho ditolak. Dari analisis tersebut, penulis dapat mengambil kesimpulan bahwa terdapat pengaruh pendidikan dasar anggota terhadap kewajiban dan tanggungjawab anggota pada KSP CU Pancur Kasih TP Bengkayang.

\section{Variabel pendidikan dasar anggota}

Secara umum, pendidikan dasar anggota pada KSP CU Pancur Kasih TP Bengkayang berdasarkan hasil penelitian menunjukan persentase sebesar sebesar $86,25 \%$ dan termasuk kedalam kategori sangat tinggi. artinya secara umum, pelaksanaan pendidikan dasar anggota memiliki pengaruh yang sangat besar 
Member Basic Training; Member Responsibilities

\section{3}

terhadap kewajiban dan tanggungjawab anggota. Di dalam pendidikan dasar berisikan materi-materi yang menerangkan tentang analisa sosial, sejarah dan prinsip dasar CU, kecerdasan finansial, perencanaan keuangan keluarga, produk dan pelayanan, pola kebijakan dan AD/ART. Dan berdasarkan hasil penghitungan peneliti menunjukkan bahwa materi pendidikan dasar KSP CU Pancur Kasih TP Bengkayang memiliki persentase sebesar $83,02 \%$ dan masuk kategori sangat tinggi.

Artinya pengetahuan anggota tentang permasalahan ekonomi dan penyebab permasalahan yang terjadi di lingkungan keluarga serta solusi untuk mengatasi semua masalah sangat tinggi, selain itu tingkat pengetahuan anggota mengenai sejarah, prinsip dasar CU, kecerdasan finansial, perencanaan keuangan keluarga serta pola kebijakan dan AD/ART juga tergolong sangat tinggi. berdasarkan kriteria analisis deskriptif persentase dapat diketahui bahwa waktu pendidikan dasar dalam pelaksanaan pendidikan dasar tergolong ke dalam kategori sangat tinggi.

Hal ini berarti bahwa waktu yang di jadwalkan oleh KSP CU Pancur Kasih TP Bengkayang bersifat kooperatif terhadap anggota karena dinilai memiliki nilai efektifitas dan efisiensi yang sangat tinggi, tempat pelaksanaan pendidikan dasar yang disediakan oleh KSP CU Pancur Kasih TP Bengkayang sangat ramah lingkungan dan mudah dijangkau oleh anggota, persepsi anggota terhadap suasana pada saat pelaksanaan pendidikan dasar sangat kondusif yang sangat menunjang dalam proses pelaksanaan pendidikan dasar, ketersediaan sarana dan prasana yang ada sangat menunjang pelaksanaan pendidikan dasar yang dilakukan oleh KSP CU Pancur Kasih TP Bengkayang.

Pada dasarnya, pendidikan dasar anggota merupakan bimbingan yang sudah terencana yang diberikan oleh orang lain yang lebih berpengalaman agar dapat terwujudkan suasana belajar dan proses pembelajaran melalui kegiatan bimbingan, pengajaran, dan atau latihan bagi peranannya di masa yang akan datang. Pelaksanaan pendidikan dasar yang dilaksanakan oleh koperasi kredit ini diharapkan dapat mengembangkan kemampuan anggota dalam mengelola sumber daya untuk menghasilkan uang serta mengelola uang tersebut dengan terencana dan bijaksana, mengenal serta mengetahui tentang perkembangan Credit Union secara umum, memahami cara pengaturan dalam keuangan keluarga, mengetahui dan memahami semua produk simpanan dan pinjaman yang ada, serta pemahaman tentang hak dan 
kewajiban serta pola kebijakan yang berlaku kepada anggota. Hal ini sesuai dengan pendapat Kadir dkk (2014:220) "Pendidikan dasar diselenggarakan untuk memberikan bekal dasar yang diperlukan untuk hidup dalam masyarakat, berupa

ember Basic

Training;

Member

Responsibilities pengembangan sikap, pengetahuan, dan keterampilan dasar”.

\section{Variabel kewajiban dan tanggungjawab anggota}

Secara umum, kewajiban anggota pada KSP CU Pancur Kasih TP Bengkayang berdasarkan hasil analisis deskriptif menunjukkan persentase sebesar 77,29\% dan termasuk ke dalam kategori tinggi, Berdasarkan hasil analisis di atas berarti tingkat kepatuhan anggota terhadap AD/ART KSP CU Pancur Kasih TP Bengkayang tergolong sangat tinggi walaupun masih ada beberapa anggota yang mengalami kredit macet dapat dilihat pada tabel 1.1. Berdasarkan hasil analisis deskriptif persentase kewajiban dan tanggungjawab anggota pada tabel 4.3, dapat diketahui bahwa besarnya persentase pada indikator "Menghadiri RAT" sebesar 58,18\%. Dimana hasil penelitian pada indikator ini menunjukan jumlah skor aktual sebesar 224 dan besarnya skor ideal pada indikator ini adalah 385. Berdasarkan kriteria analisis deskriptif persentase maka keaktifan anggota dalam menghadiri RAT dapat dikatakan cukup. Persentase pada indikator "membayar kredit" sebesar 84,41\% maka keaktifan anggota dalam membayar kredit dapat dikatakan tergolong sangat tinggi, kepatuhan anggota dalam membayar simpanan dapat dikatakan tergolong sangat tinggi.

Secara umum, tanggungjawab anggota pada KSP CU Pancur Kasih TP Bengkayang berdasarkan hasil analisis deskriptif menunjukkan persentase sebesar $63,11 \%$ dan termasuk ke dalam kategori tinggi. berdasarkan hasil wawancara dengan Branch Manager KSP CU Pancur Kasih TP Bengkayang secara umum tingkat partisipasi anggota terhadap kegiatan usaha sudah baik, hampir seluruh anggota sudah melakukan pinjaman dan mengikuti RAT. Hal ini dapat dibuktikan dari hasil jawaban sebaran angket responden yang hampir dari seluruh responden telah berpartisipasi dalam kegiatan usaha dengan baik, walaupun masih ada beberapa diantara anggota yang belum pernah melakukan pinjaman dan mengikuti RAT, anggota hanya aktif menabung. Dalam bermitra memang diperlukan jalinan kebersamaan yang ditandai dengan bentuk kerjasama, baik kerjasama tersebut 
Member Basic Training;

Member

Responsibilities

\section{5}

dilakukan terhadap CU sebagai mitra ataupun terhadap sesama anggota. Turut serta pula dalam kerjasama di atas, yakni diharapkan masing-masing pihak mampu menjaga dan menumbuhkembangkan nilai-nilai kebersamaan yang sudah ada tersebut.

Pada dasarnya dalam setiap perkumpulan akan selalu terdapat kewajiban, tanggung jawab dan hak anggota terhadap perkumpulannya tersebut. Demikian pula halnya dalam perkumpulan koperasi terdapat kewajiban, tanggung jawab, dan hak anggota yang harus dipenuhi agar koperasi tersebut dapat menjalankan usahanya dengan baik. Sebelum menuntut haknya, seorang anggota koperasi terlebih dahulu harus memenuhi kewajiban dan tanggung jawabnya. Berikut menurut Sanjaya (2015) "Tanggungjawab diartikan sebagai keadaan wajib menanggung segala sesuatunya jika terjadi apa-apa boleh dituntut, dipersalahkan, diperkarakan atau juga berarti hak yang berfungsi menerima pembebanan sebagai akibat sikapnya oleh pihak lain".

\section{PENUTUP}

\section{Kesimpulan}

Dari hasil penelitian dan pembahasan analisis data yang telah dilakukan oleh penulis, maka dapat diperoleh kesimpulan sebagai berikut:

1. Berdasarkan hasil penelitian yang telah dilakukan oleh peneliti maka dapat diperoleh persentase hasil penelitian variable pendidikan dasar anggota sebesar $86,25 \%$ berada pada kategori sangat tinggi. Hal ini menunjukan bahwa pendidikan dasar anggota KSP CU Pancur Kasih TP Bengkayang yang didalamnya terdapat indikator materi, waktu, tempat, suasana, sarana dan prasarana pendidikan dasar memiliki tingkat kesesuaian antara ketersediaan dengan harapan yang tergolong sangat tinggi. Dalam artian pelaksanaan pendidikan dasar telah memenuhi syarat serta kriteria yang ada.

2. Berdasarkan hasil penelitian yang dilakukan oleh peneliti untuk mengetahui bagaimana kewajiban anggota pada KSP CU Pancur Kasih TP Bengkayang setelah mengikuti pendidikan dasar diperoleh data sebesar 77,29\%. Maka, dapat diberi penilaian bahwa anggota memiliki persentase akan kewajibannya pada KSP CU Pancur Kasih TP Bengkayang yang tergolong tinggi. 
3. Berdasarkan hasil penelitian yang dilakukan oleh peneliti untuk mengetahui bagaimana tanggung jawab anggota pada KSP CU Pancur Kasih TP Bengkayang setelah mengikuti pendidikan dasar diperoleh data sebesar 63,11\%. Maka, dapat diberi penilaian bahwa anggota memiliki persentase akan tanggungjawabnya pada KSP CU Pancur Kasih TP Bengkayang yang tergolong tinggi.

4. Berdasarkan hasil penelitian dapat ditarik kesimpulan bahwa pendidikan dasar anggota memberi pengaruh positif terhadap kewajiban dan tanggungjawab anggota. Hal ini diketahui berdasarkan output nilai hasil perhitungan SPSS 20.0 seperti yang telah dijabarkan sebelumnya.

\section{Saran}

Berdasarkan hasil penelitian dan kesimpulan yang telah dipaparkan oleh penulis, maka adapun saran-saran yang dapat diberikan sebagai berikut:

1. Hasil penelitian ini, peneliti berharap agar dapat dilakukanya penelitian lebih lanjut yang berguna untuk memperjelas pengaruh pendidikan dasar anggota terhadap kewajiban dan tanggungjawab anggota. Peneliti juga berharap agar dilakukan penelitian lebih lanjut mengenai faktor yang mempengaruhi kewajiban dan tanggungjawab anggota pada KSP CU Pancur Kasih TP Bengkayang.

2. Bagi koperasi, penelitian ini diharapkan dapat memberikan sumbangan pemikiran kepada pihak manajemen / pengurus serta karyawan di KSP CU Pancur Kasih TP Bengkayang dalam upaya meningkatkan kesadaran anggota akan kewajiban dan tanggungjawab anggota melalui pelaksanaan pendidikan dasar yang lebih baik lagi.

3. Bagi perguruan tinggi penelitian ini diharapkan dapat memberikan kontribusi karya ilmiah berbentuk Laporan Akhir atau Skripsi dan diharapkan juga dapat bermanfaat bagi pembaca. yang memerlukan informasi yang berhubungan dengan penelitian ini. 


\section{DAFTAR PUSTAKA}

CU Pancur Kasih. 2020. Peraturan Pengurus, KSP CU Pancur Kasih: Pontianak.

CU Pancur Kasih. 2019. Peraturan Pengurus dan AD/ART, KSP CU Pancur Kasih: Pontianak

CU Pancur Kasih. 2019. Laporan RAT TB 2019, KSP CU Pancur Kasih: Pontianak.

Hogarth, Jeanne M. 2006. Financial Education and Economic Development. Paper presented in International Conference of Financial Literacy Improvement by G8 Russian Presidency and OECD.

McKillop, Donal G. \& John O. S. Wilson. 2015. Credit Unions as Cooperative Institutions: Distinctiveness, Performance and Prospects (Working Paper 15003). The Centre for Responsible Banking and Finance: University of St Andrews.

Munaldus, Yuspita Karlena, \& Herlina. 2014. Kiat Mengelola Credit Union. Jakarta: Elex Media Komputindo.

OECD. 2005b. Improving Financial Literacy: Analysis of Issues and Policies. Organisation for Economic Cooperation and Development.

Priyatno, Duwi. 2013. Mandiri Belajar Analisis Data Dengan SPSS. Yogyakarta: Mediakom.

Republik Indonesia. 1992. Undang-undang No. 25 tahun 1992 tentang perkoperasian. Bandung: Dinas Koperasi.

Sudarsono. 2014. Manajemen Koperasi Indonesia. Jakarta: Rineka Cipta.

Yoong, Joanne \& Vera Rita De Mello Ferreira. (2011). Improving Financial Education Effectiveness through Behavioural Economics: OECD Key Findings and Way Forward. The World Bank and Ministry of Finance of The Russian Federation. 